\title{
Congenital Systemic Disorder
}

National Cancer Institute

\section{Source}

National Cancer Institute. Congenital Systemic Disorder. NCI Thesaurus. Code C97151.

An inherited disorder that presents with systemic manifestations. 